\title{
Studies on the Biochemical Marker Loci Detected with Urine, Tears, and Saliva of Rats
}

\author{
Yasushi KONDO \\ Safety Research Laboratory, Tanabe Seiyaku Co., Ltd., 3-16-89 Kashima, \\ Yodogawa-ku, Osaka-shi, Osaka 532, Japan
}

I. Introduction

Contents

II. Detection of the biochemical loci

1. Linkage analysis of urinary pepsinogen-1

2. Male urinary protein -1 expression in the female rat

3 . Genetic polymorphisms of tear proteins

4. Genetic polymorphisms of salivary proteins

III. Conclusion

\section{I . Introduction}

There are many inbred mice strains, and outbred (closed colony) mice have been replaced by inbred mice and their $F_{1}$ hybrids in biomedical research, because of their genetic uninformity and their defined genetic constitution. Also in rats, the total amount of inbred strains used in biomedical researches and also the number of inbred strains has been increasing year after year. Throughout the world, more than 200 distinct inbred strains have been developed. However, the number of marker genes and linkage groups that can be used in genetic monitoring are scarce, and the chromosomal locations of genes have not been known until a few years ago. This study was performed to examine the biochemical loci detected with urine, tears and saliva, which can be obtained without killing the animals, for use in identification of each inbred strain and in the genetic monitoring of rats.

\section{Detection of the biochemical loci}

1. Linkage analysis of urinary pepsinogen-1

Weitkamp et al. [49] reported that the electrophoretic mobility of urinary pepsinogen was polymorphic in human beings and the locus has been linked to the $H L A$ of the human major histocompatibility complex (MHC), and Gedde-Dahl et al. [18] have suggested that the $P g$ locus might be located on the terminal part of the short arm of chromosome 6 . Szymura and Klein $[45,46]$ reported that urinary pepsinogen (UPG-1) in mice was also polymorphic among the laboratory mice and the gene was closely linked to the $\mathrm{H}-2$ of mouse MHC (6 $\mathrm{cM})$, while the Upg-2 locus was located on chromosome 1 [47]. On the other hand, Cramer [11] found polymorphism in urinary pepsinogen-1 (PG-1) of the laboratory rat, and PG-1 was controlled by a single autosomal locus with two alleles of $P g-1^{a}$ and $P g-1^{b}$. However, he suggested that the $P g-1$ locus independently segregated from the $R T 1$ of the rat MHC but loosely linked to a coat color locus of albinism $(30 \mathrm{cM})$.

The $c$ locus belongs to the rat linkage group (LG) I which also contains the $\mathrm{Hbb}$ locus. To determine their linear order, we performed a three point test on $\mathrm{Pg}-1, \mathrm{c}$, and $\mathrm{Hbb}$ loci [29].

The collected urine samples were electrophoresed on agar gel according to the method of Samloff [40]. Electrophoresed urinary pep:

本論文は第40回日本実験動物学会総会 (1993年 6 月 2 日〜 4 日於, 仙台国際センター) における第 5 回日本実験動物学会 賞受賞講演の内容を要約したものである。 
Table 1. Linkage tests of $P g-1$ with 6 loci in the progeny rats of $[(\mathrm{WF} \times \mathrm{IS}) \times \mathrm{WF}]$ backcross

\begin{tabular}{|c|c|c|c|c|c|c|c|}
\hline \multirow{2}{*}{ Locus } & \multirow{2}{*}{ LG } & \multicolumn{2}{|c|}{ Progenitor's genotype } & \multirow{2}{*}{ Genotype } & \multicolumn{2}{|c|}{$P g-1$} & \multirow{2}{*}{$x^{2}$ for linkage } \\
\hline & & WF & IS & & $a a$ & $a b$ & \\
\hline \multirow[t]{2}{*}{$c$} & \multirow[t]{2}{*}{ I } & \multirow[t]{2}{*}{$c c$} & & $c c$ & 20 & 19 & \multirow[t]{2}{*}{0.223} \\
\hline & & & $C C$ & $C c$ & 16 & 21 & \\
\hline \multirow[t]{2}{*}{$H b b$} & \multirow[t]{2}{*}{ I } & \multirow[t]{2}{*}{$a a$} & & $a a$ & 22 & 18 & \multirow[t]{2}{*}{0.867} \\
\hline & & & $b b$ & $a b$ & 15 & 21 & \\
\hline \multirow[t]{2}{*}{$M u p-1$} & \multirow[t]{2}{*}{ II } & \multirow[t]{2}{*}{$b b$} & & $b b$ & 20 & 20 & \multirow[t]{2}{*}{0.065} \\
\hline & & & $a a$ & $a b$ & 16 & 20 & \\
\hline \multirow[t]{2}{*}{$a$} & \multirow[t]{2}{*}{ IV } & \multirow[t]{2}{*}{$a a$} & & $a a$ & 9 & 10 & \multirow[t]{2}{*}{0.035} \\
\hline & & & $A A$ & $A a$ & 7 & 11 & \\
\hline \multirow[t]{2}{*}{$E s-3$} & \multirow[t]{2}{*}{$\mathrm{V}$} & \multirow[t]{2}{*}{$c c$} & & $c c$ & 18 & 20 & \multirow[t]{2}{*}{0.000} \\
\hline & & & $b b$ & $b c$ & 18 & 20 & \\
\hline \multirow[t]{2}{*}{$h$} & \multirow[t]{2}{*}{ VI } & \multirow[t]{2}{*}{$h h$} & & $h h$ & 8 & 9 & \multirow[t]{2}{*}{0.010} \\
\hline & & & $H H$ & $H h$ & 8 & 12 & \\
\hline
\end{tabular}

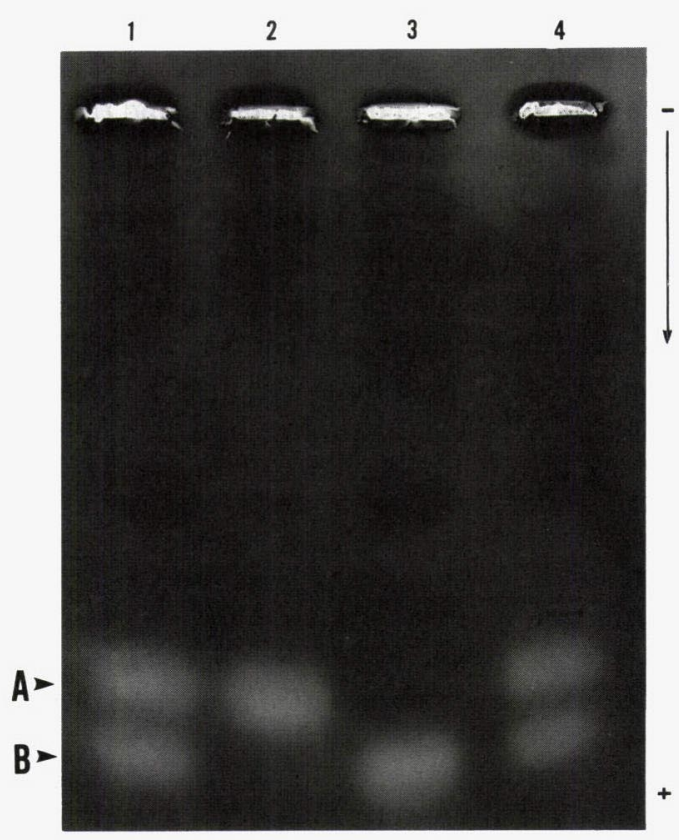

Fig. 1. Agar gel electrophoresis of rat urinary pepsinogen Lane 1: (WF $\times$ IS) $F_{1}$ Lane $2: W F$ Lane $3:$ IS Lane $4:$ mixed sample from equal volumes of IS and WF

sinogen showed two types (Fig. 1) ; slow migrating banding pattern (type $\mathrm{A}: \mathrm{ACI}, \mathrm{BN}$, DONRYU, LEW, and WF) and fast migrating pattern (type B; BUF, F344, IS, WKYO, SHR, TM, W, and WKAM). The $\mathrm{F}_{1}$ hybrids between WF and IS exhibited two bands, each corresponding to either one parental band or another. Among the 76 progenies of the [ (WF $\mathrm{x}$ IS) $\mathrm{F}_{1} \mathrm{x}$ WF] backcross, two types were segregated ; 40 were type $\mathrm{AB}$ and 36 were type A. Since the $\chi^{2}$ value for expectation of the 1 : 1 segregation ratio was very low, we reconfirmed the findings of Cramer [11] that the urinary pepsinogen is inherited as a single autosomal trait and that the $P g-1$ locus possesses two co-dominant alleles of $P g-1^{a}$ and $P g-$ $1^{b}$.

In the same backcross progenies, we found linkage between the $c$ and $H b b$ loci $\left(\chi^{2}=47.366\right.$, recombination frequency $=10.5 \pm 3.5$ ) (Table $1)$, which coincided with the previously reported value $[16,36]$, but linkages of $P g-1$ to $c$ and $\mathrm{Hbb}$ loci were not detected $\left(\chi^{2} \mathrm{~s}\right.$ for linkage were 0.223 and 0.867 , respectively). The linkage between the $P g-1$ and $c$ reported by Cramer [11] was rather remote $(30 \mathrm{cM})$, but our value was $53.0 \pm 5.7$ corrected by three double crossingovers between $P g-1$ and $c$ loci on the assumption that the linear order was $P g$ $-1-H b b-c$. We would like to rule out the linkage between $P g-1$ and $c$. Also $P g-1$ was not linked to $M u p-1$ (LG II), $a$ (LG IV), $E s-3$ (LG V), and $h$ (LG VI) (Table 1). Pg-1 will be one of the most valuable genetic markers of rats, since $P g-1$ was highly polymorphic among inbred strains of rats, and not linked to linkage group I, II, IV, V, and VI. 
2. Male urinary protein -1 expression in the female rat

Rats and mice normally excrete proteins in the urine, but the amount excreted by rats is much less than that excreted by mice [42]. In the mouse, major urinary proteins migrate as prealbumins after starch gel electrophoresis and their expressions are controlled by a single gene (major urinary protein, $M u p-1$ ) on chromosome $4[15,19]$. On the other hand, in rats, van Zutphen et al. [48] first detected polymorphic urinary proteins and we also reported [38] that the urinary proteins in the male rat could be detected on the polyacrylamide gel electrophorogram by urine concentrated 25-50 times and we first found that the locus is closely linked with the brown (b) coat-color locus in LG II as in mice. Since in urine from female rats, we could detect no MUP-1 in the zone where urine from males exhibited polymorphism among inbred strains, we named the protein as male urinary protein-1 (MUP-1) . However, using female urine concentrated 100 -150 times, we could detect a protein in the zone in which the male MUP-1 is present on the polyacrylamide gel electrophorogram [28] .

The banding pattern of female MUP- 1 was only slightly different from that of the male MUP-1. As shown in Fig. 2, female urine samples from different inbred strains showed two bands at positions corresponding to that of the male MUP-1; the cathodal band was intensely stained and had mobility polymorphisms among the 12 inbred strains tested (ACI, BN, DONRYU, IS, LEW, SHR, TM, $\mathrm{W}, \mathrm{WAG}, \mathrm{WB}, \mathrm{WF}$, and $\mathrm{WM}$ ). The anodal band was faintly stained, corresponding to the first band of the male MUP-1, and showed no polymorphism. Based on the different mobility of the cathodal intensely stained band, the bands were tentatively designated as A type (faster) and B type (slower). The 12 inbred strains tested belonged to either the A or B type and were completely homologous with the male MUP-1 type. The $\mathrm{F}_{1}$ hybrids between ACI (B type) and BN (A type) showed three bands.

To confirm the linkage between $M u p-1$ and $b$ in females, 35 female and 31 male progenies from the [( $\left.\mathrm{ACI} \times \mathrm{BN}) \mathrm{F}_{1} \times \mathrm{BN}\right]$ backcross were examined for their coat color and MUP-1 types. As shown in table 2, there was a high correlation between $M u p-1$ and $b\left(\chi^{2}=\right.$ $20.907)$ in females, and the recombination fre-
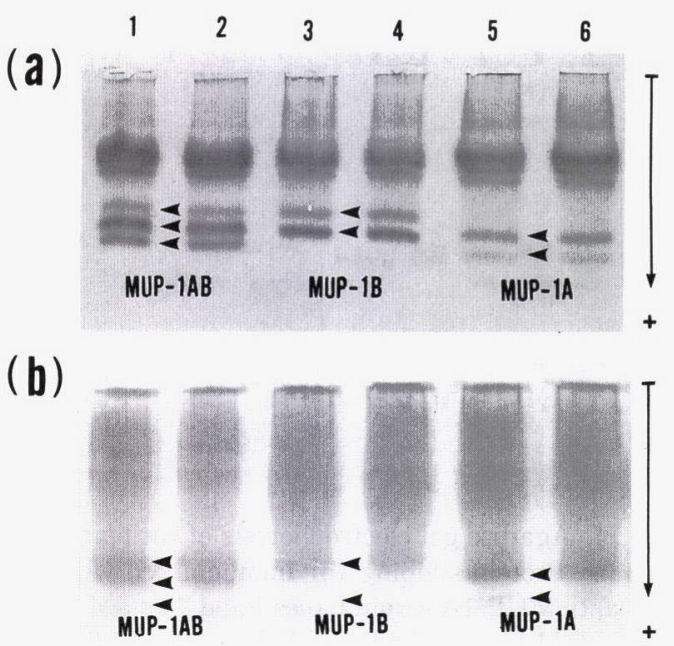

Fig. 2. Polyacrylamide slab gel electrophoresis of rat MUP-1 (a) Male (b) Female Lanes 1 and 2: $(\mathrm{ACI} \times \mathrm{BN}) \mathrm{F}_{1}$ hybrid Lanes 3 and $4: \mathrm{ACI}$ Lanes 5 and $6:$ BN

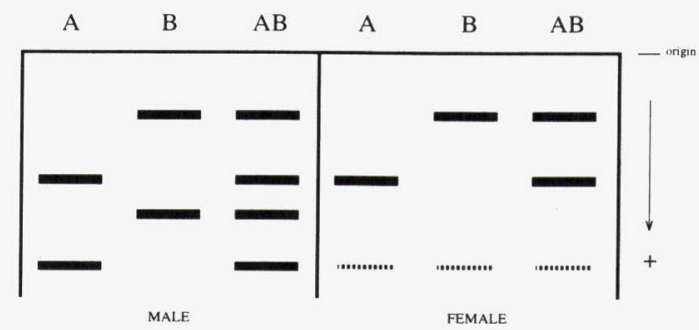

Fig. 3. Schematic representations of electrophoretic pattern of MUP-1 in male and female rats

Table 2. Recombination of $M u p-1$ and $b$ in the progeny of $\left[(\mathrm{ACI} \times \mathrm{BN}) \mathrm{F}_{1} \times \mathrm{BN}\right]$ backcross ${ }^{*}$

\begin{tabular}{|c|c|c|}
\hline Genotype & female & male \\
\hline \multicolumn{3}{|l|}{ Parental } \\
\hline$M u p-1^{a} b / M u p-1^{a} b$ & 16 & 14 \\
\hline$M u p-1^{b} B / M u p-1^{a} b$ & 16 & 14 \\
\hline \multicolumn{3}{|l|}{ Recombinant } \\
\hline$M u p-1^{a} B / M u p-1^{a} b$ & 1 & 1 \\
\hline Mup $-1^{b} b / M u p-1^{a} b$ & 2 & 2 \\
\hline \multicolumn{3}{|l|}{ Total } \\
\hline$x^{2}$ for linkage & 20.907 & 17.148 \\
\hline Recombination frequency & $8.6 \pm 4.7$ & $9.7 \pm 5.3$ \\
\hline
\end{tabular}

quency of $8.6 \pm 4.7$ percent was very close to that observed in males $(9.7 \pm 5.3$ percent) . 
(a)

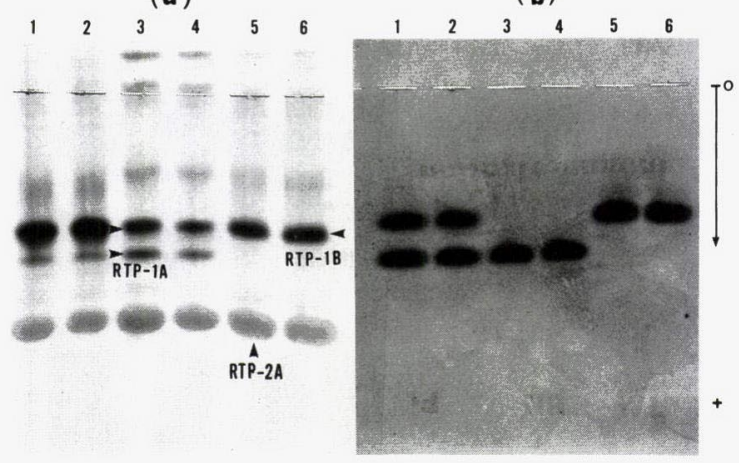

Fig. 4. Agarose gel electrophoresis of rat tear proteins (a) Protein staining (b) Immunofixed with rabbit anti-MUP-1A serum Lanes 1 and $2:(\mathrm{TM} \times \mathrm{BN}) \mathrm{F}_{1}$ hybrid Lanes 3 and $4: \mathrm{BN}$ Lanes 5 and $6: \mathrm{TM}$

Furthermore, polyclonal antisera made against the male MUP-1A reacted with female $\mathrm{MUP}-1 \mathrm{~A}$, and the male and female MUP-1B were electrophoresed on agarose gels. MUP-1A and MUP-1B were purified using monoclonal antibodies against the male MUP-1A that were established by fusion of mouse myeloma and spleen cells obtained from mice immunized with crude MUP-1A. The molecular weights of purified MUP-1A and MUP-1B were both estimated to be 18,000 daltons by sodium dodecyl sulfate-polyacrylamide gel electrophoresis (SDS-PAGE). These findings suggest that the MUP-1 types in female urine are expressions of the same alleles found in males, although the patterns are slightly different.

As schematically shown in Fig. 3, there seem to be four components of MUP-1 of rats ; these are tentatively named sequentially $1,2,3$, and 4 from the anode. Although the degree of expression of all the components is sex dependent, as seen in the urine concentration required in the females (100-150 times) and in the males (25-50 times), the extent varies between components: component 2 is the most sex dependent, component 1 intermediate, and components 3 and 4 equally the least sex dependent. The fact that the male MUP$1 \mathrm{~B}$ does not have component 1 while the female MUP-1B does, and that male MUP-1A has component 1 while the female MUP-1A and MUP-1B each have it, may simply indicate that the male MUP-1B has component 1 but it is produced in a very low quantity, and the androgenic induction rates of component 1 may differ between MUP-1A and MUP-1B. From the suspected androgenic inducibility of the male MUP-1 expression, the expression of the $M u p-1$ gene may reflect the hormonal inducibility of MUP-1 proteins, and may not control the synthesis of each component, as had been proposed for the mouse $M u p-1$ gene [44].

3. Gentic polymorphisms of tear proteins

Human tears can be separated into at least 14 protein fractions by polyacrylamide or agarose gel electrophoresis [41]. Azen [2] reported that the electrophoretic mobility of the most anodal tear protein was genetically polymor phic. The protein in mouse tears can be separated into $15-20$ protein components by polyacrylamide gel electrophoresis. Four of these components were found to be polymorphic and the genetic loci have been detected. These were designated mouse tear protein system $1,2,3$, and $4(M t p-1,2,3$, and 4$),[31,33,34,35]$. Using agarose gel electrophoresis, we could find two polymorphisms were found in the tear proteins of inbred strains of rats $[24,25,26]$.

Rat tears obtained by subcutaneous injection of $0.1 \%$ pirocarpine hydrochloride were electrophoresed on agarose gel. As shown in Fig. $4 \mathrm{a}$, in the most intensively stained and the middle anodic zone, the strains $\mathrm{BN}$, DONRYU, Donryu, IS, LEJ, LEM, LET, PVG, SHR, TOM, and WKYO had two bands (RTP-1A), while the strains $\mathrm{ABH}, \mathrm{ACI}$, ALB, BDIX, BUF, F344, JC, LEW, LOU, NIG-III, SDJ, TM, TO, W, WA, WAG, WBN, WKAH, WKAM, WKS, WM, and WN had only one band at almost the same position as the slower band of RTP-1A (RTP1B).$F_{1}$ hybrids of ( $\left.B N \times T M\right)$ had two bands, and backcross progenies of the $F_{1}$ hybrids to $\mathrm{TM}$ were segregated into $\mathrm{AB}$ and $\mathrm{B}$ types (37; $\left.30, x^{2}=0.731\right)$. We tentatively designated the locus at $R t p-1$ (rat tear protein -1) with two co -dominant alleles of $R t p-1^{a}$ (with two bands) and $R t p-1^{b}$ (with a single band). Among the 67 backcross progenies, no recombinants were found between $R t p-1$ and $M u p-1$, which belongs to linkage group II. Table 3 shows the distributions of the Rtp-1 and $M u p-1$ genotypes among the 34 inbred strains tested. LEJ had the $R t p-1^{a}$ and $M u p-1^{b}$ alleles; $\mathrm{ABH}$ and WKAM had the $R t p-1^{b}$ and $M u p-1^{a}$ alleles. All other strains with the $R t p-1^{a}$ allele had the $M u p-1^{a}$ allele, and all other strains 
Table 3. Strain distributions of $R t p-1$ and $M u p-1$ genotypes among 34 inbred strains of the rat

\begin{tabular}{|c|c|c|}
\hline \multirow{2}{*}{$M u p-1$} & \multicolumn{2}{|c|}{$R t p-1$} \\
\hline & $a a$ & $b b$ \\
\hline$a a$ & $\begin{array}{l}\text { BN, Donryu, DONRYU, IS, } \\
\text { LEW, LET, PVG, SHR, } \\
\text { TOM, WKYO }\end{array}$ & ABH, WKAM \\
\hline$b b$ & LEJ & $\begin{array}{l}\text { ACI, ABL, BDIX, BUF, JC, } \\
\text { F344, LEO, LEW, LOU, TM, } \\
\text { NIG-III, SDJ, TO, W, WAG, } \\
\text { WA, WBN, WKAH, WKS, } \\
\text { WM, WN }\end{array}$ \\
\hline
\end{tabular}

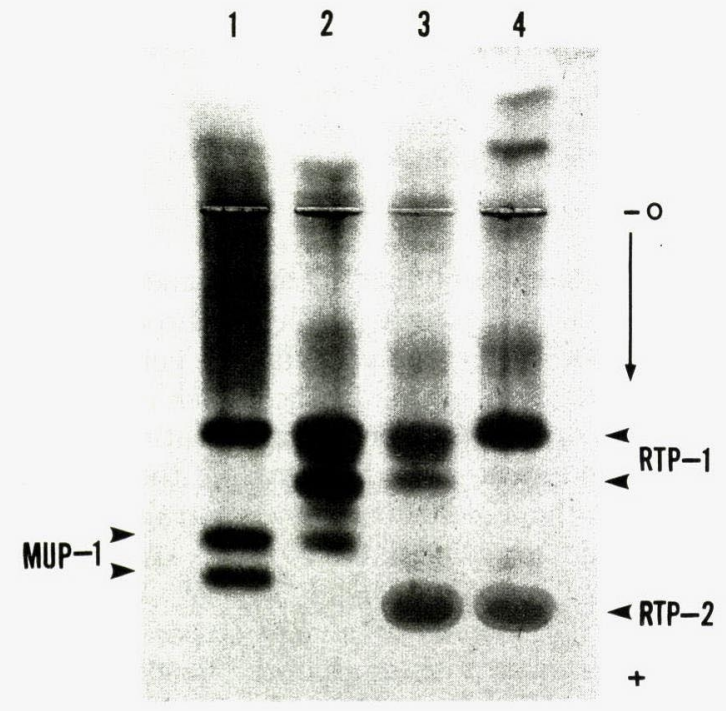

Fig. 5. Agarose gel electrophoretic patterns of tear and urine samples Lane $1: \mathrm{BN}$ urine Lane 2: SHR tear Lane 3:BN tear Lane 4: TM tear

with the $R t p-1^{b}$ allele had the $M u p-1^{b}$ allele. These findings strongly suggest that the two loci are located at different positions but that they are very closely linked.

After the tear samples were electrophoresed in agarose gel and immunofixed with rabbit-anti MUP-1A sera, the faster band of RTP$1 \mathrm{~A}$ and one band of RTP-1B were clearly detected using the sera (Fig. 4b), but the slower band of RTP-1A was not. However, as shown in Fig. 5, the RTP-1 protein clearly migrated more slowly than the MUP-1 protein . Furthermore, the molecular weight of RTP-1A and RTP-1B purified with monoclonal antibodies against the MUP-1 were both estimated to be 17,000 daltons by SDS-PAGE. This indi-

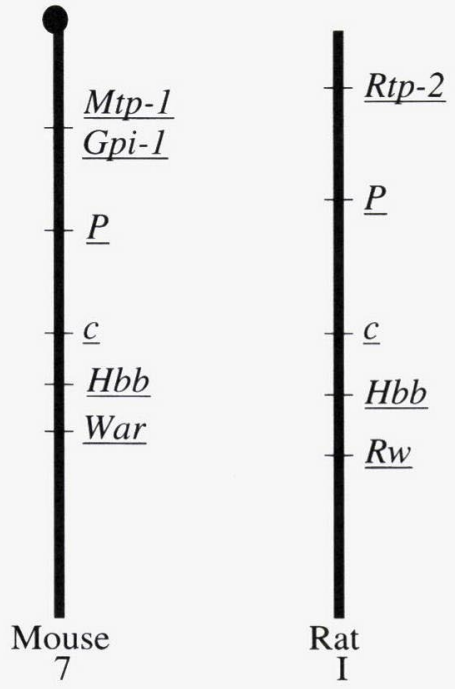

Fig. 6. Homologous gene assignment on mouse chromosome 7 and rat linkage group I

cates that RTP-1 proteins are different molecules from MUP-1 proteins in spite of sharing the same antigenicity. These findings suggest that $\mathrm{RTP}-1$ proteins and MUP-1 proteins are members of the same family of proteins and that $R t p-1$ and $M u p-1$ may also belong to the same gene family.

In BDIX, DA, LE, LEA, LEJ, LEO, LET, and SHR strains the fastest migrating band was missing (RTP-2B), whereas ABH, ACI, ALB, BN, BUF, DONRYU, Donryu, F344, IS, JC, LEM, LOU, NIG-III, PVG, SDJ, TM, TO, W, WA, WAG, WKAH, WKAM, WKS, WKYO, and WM strains had the band (RTP-2A) (Fig. 5). The $F_{1}$ hybrids of (SHR x ACI) also had the band, and back- 
(a)

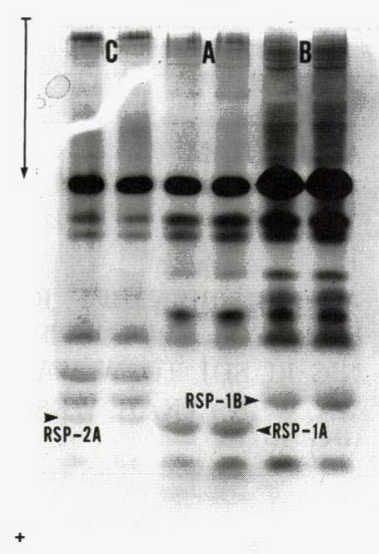

(b)
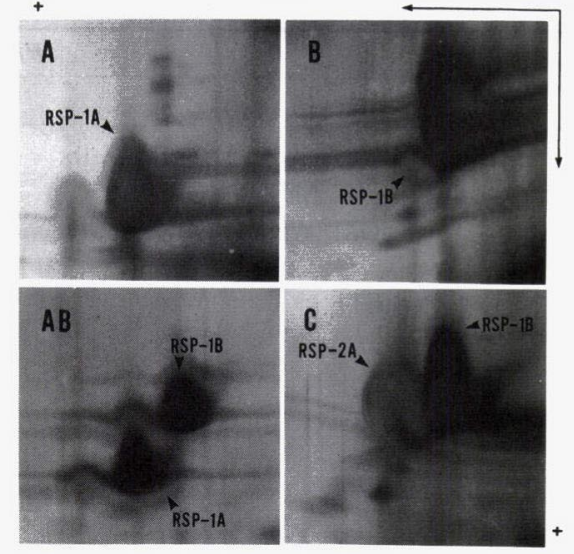

Fig. 7. Zymograms of RSP-1 and RSP-2 (a) Typing gel electrophoresis (b) Two-dimensional polyacrylamide electrophoresis A : IS B : ACI C : F344 AB : (ACI x IS) $F_{1}$ hybrid

cross progenies of the $F_{1}$ to SHR were segregated into $\mathrm{AB}$ and $\mathrm{B}$ types $\left(34: 45, \chi^{2}=1.513\right)$. We tentatively designated the locus as $R t p-2$ (rat tear protein-2) with two alleles of $R t p-2^{a}$ (with a band) and $R t p-2^{b}$ (without band) . Linkage analyses gave a significant but not high chi-square value between the $R t p-2$ and $c$ loci. Since $c$ and $H b b$ loci belong to linkage group I and both were tested, we calculated the distance from $R t p-2$ to $c$ and $H b b$ on the linkage group $\mathrm{I}$ as $36.7 \pm 5.4 \mathrm{cM}$ and $39.7 \pm$ $5.5 \mathrm{cM}$, respectively. As shown in Fig. 6, Rtp2 in the rat appears to be located from $p$ to the proximal end, with their linear order being $R t p$ $-2-p-c-H b b$. This order is quite similar to that in mouse chromosome 7 [34]. Thus Rtp-2 in the rat can be considered to be homologous with $M t p-1$ in the mouse.

4. Genetic polymorphisms of salivary proteins

The genetic polymorphism of many salivary proteins of humans has been described. At least 12 loci, $\operatorname{Pr}[4,9], P a[3,17], D b[4]$, Pmf [20], PmS [5,23], Ps [5], Gl [39], CON1 [7], CON2 [7], $\mathrm{Pe}[8], \mathrm{PO}_{0}[8]$, and $P c$ [22] have been detected by PAGE or starch gel electrophoresis. On the other hand, in mice, these salivary protein loci, Ssp [21], $A b p[12$, 13 ], and $M s p-1$ [32] have been found by polyacrylamide gel electrophoresis. Using polyacrylamide gel electrophoresis, we have found two polymorphisms in the salivary proteins among inbred strains of rats [27] .
Rat saliva obtained by subcutaneous injection of $0.1 \%$ pirocarpin hydrochroride was electrophoresed on polyacrylamide gel. Fig. 7a shows the zymograms of the rat salivary proteins. Some electrophoretic variations were observed among inbred strains. Of these variations, in the middle anodic zone, strains IS and LEW had an anodal band (RSP-1A), while strains ACI, BN, BUF, F344, W, WF, and WKYO had a band at almost the same but a slightly slower position than the band of RSP1A (RSP-1B) . $F_{1}$ hybrids of (ACI $x$ IS) had two bands, and the backcross progenies of $F_{1}$ hybrids to IS were segregated into $\mathrm{AB}$ and $\mathrm{A}$ types $\left(42: 53, x^{2}=1.274\right)$. We tentatively designated the locus as $R s p-1$ (rat salivary protein-1) with two co-dominant alleles, $R s p$ $1^{a}$ (with an anodal band) and $R s p-1^{b}$ (with a slower band). In the same backcross progenies, we were able to test for linkages of $R s p-$ 1 to $A c p-2$ (LG?), $E s-3$ (LG V), $E s-4$ (LG V), $L a p-1$ (LG I ), $M u p-1$ (LG II), $P g-1$ (LG?), Pgd (LG II), Rtp-1 (LG II), and Svp -1 (LG IV). None of the loci were linked to Rsp -1 .

In the zone between RSP-1A and RSP-1B, strains BN, BUF, F344, W, and WF had a band of a slightly slower mobility than that of RSP-1A (RSP-2A) (Fig. 7a), but the band was missing in strains ACI, IS, LEW, and WKYO (RSP-2B). The two-dimensional electrophoresis showed that the RSP-2A proteins were 
different from RSP-1A proteins (Fig. 7b). The $\mathrm{F}_{1}$ hybrids of (ACI $\times$ F344) also had a band, and backcross progenies of the $\mathrm{F}_{1}$ to $\mathrm{ACI}$ were segregated into $\mathrm{AB}$ and $\mathrm{B}$ types $\left(49: 40, \chi^{2}=\right.$ $0.910)$. We tentatively designated the locus as $R s p-2$ (rat salivary protein-2) with two alleles, $R s p-2^{a}$ (with a band) and $R s p-2^{b}$ (without a band) ; $R s p-2^{a}$ was dominant over $R s p-$ $2^{b}$. The linkage study on the backcross progenies indicated that the $R s p-2$ was not linked with $A m y-1$ (LG?), $E s-1$ (LG V), $E s-6$ (LG?) , $H b b$ (LG I ), Lap-1 (LG I ), Pep-3 (LG X), or Pg-1 (LG?) .

In humans, closely linked loci that determine many salivary proteins have been identified by population and family studies. This linkage group constitutes the SPC (salivary protein gene complex) [33]. The SPC codes for many biochemically and immunologically closely related proline-rich proteins (PRPs) whose biochemistry, genetics and functional properties have been reviewed [10] . PRPs have been isolated from mouse [4], rat $[14,37]$ and monkey [1] parotid glands. Human and mouse PRP genes have been mapped to chromosomes 12 [30] and $6[6]$, respectively. Rat PRPs will probably be localized to chromosome 4 , since some mouse chromosome 6 genes, such as, Cpa, Try-1, Npy, Fabp-1, and Pthlh, have counterparts throughout rat chromosome 4 [43]. Both $R s p-1$ and $R s p-2$ may be PRPs.

\section{Conclusion}

(1) We reconfirmed that the urinary pepsinogen was inherited as a single autosomal trait and the $\mathrm{Pg}-1$ locus possessed two $\mathrm{CO}^{-}$ dominant alleles of $P g-1^{a}$ and $P g-1^{b} . P g-1$ was not linked with albinism in linkage group I . (2) The expression of $M u p-1$ in females showed polymorphism that was confirmed to be controlled by the same alleles as those observed at the male $M u p-1$ locus, although the electrophoretic pattern was slightly different. (3) Two genetic polymorphisms of rat tear proteins were found by agarose gel electrophoresis, rat tear protein-1 and $-2(R t p-1, R t p-2)$. (4) Two genetic polymorphisms of rat salivary proteins were found by polyacrylamide gel electrophoresis, rat salivary protein -1 and $-2(R s p-1, R s p$ $-2)$.

Recently, Serikawa et al. reported the chromosome assignment of rat genes and linkage groups by using PCR-analyzed microsatellites, showing that the $M u p-1, R t p-1$, and $R t p-2$ are located on chromosome 5, 5, and 1 , respectively [43]. We should be able to map the $P g-1, R s p-1$, and $R s p-2$ in the near future. The newly confirmed and developed loci in this study will be effective and useful as additional marker genes for the genetic monitoring of the rat.

The author would like to thank Professor Dr. M. Ishibashi, Azabu University, Director Dr. K. Kondo, Laboratory of Experimental Animals, Yagi Memorial Park, Director Dr. T. Imamichi, Imamichi Institute for Animal Reproduction, and Professor Dr. N. Goto, Kobe University for recommending him as a candidate for the 5th JALAS prize. The author is deeply indebted to Professor Dr. J. Yamada and Associate Professor Dr. T. Serikawa, Kyoto University for guidance him of this study. The author is also grateful to Professor Dr. J. Hayakawa and Dr. H. Nikaido, Kanazawa University for their variable suggestions. The author wishes to thank the staff of the Institute of Laboratory Animals, Faculty of Medicine, Kyoto University for their cooperation, encouragement, and useful discussion.

\section{References}

[1] Arneberg, P., Helgeland, K., and Tjornhom, T. (1976). Proline-rich proteins in membranes and contents of monkey (Macaca irus and Ercopithecus aethiops) parotid zymogen granules. Arch. Oral Biol., 21, 379-383.

[2] Azen. E. A. (1976). Genetic polymorphism of human anodal tear protein. Biochem. Genet., 14, 225-235.

[3] Azen, E. A. (1977). Salivary peroxidase (SAPX) genetic modification and relationship to proline-rich $(\mathrm{Pr})$ and acidic $(\mathrm{Pa})$ proteins in human parotid saliva. Biochem. Genet., 15, 9-29.

[4] Azen, E. A. and Denniston, C. L. (1974). Genetic polymorphism of human salivary proline-rich proteins: Further genetic analysis. Biochem. Genet., 12, 109-120.

[5] Azen, E. A. and Denniston, C. L. (1980). Polymorphism of Ps (parotid size variant) and detection of a protein $(\mathrm{PmS})$ related to the $\mathrm{Pm}$ (parotid middle band) system with genetic linkage of $P s$ and $P m$ to $G l$, $D b$, and $P r$ genetic determinants. Biochem. Genet., 18, 483-501.

[6] Azen, E. A., Lush, I. E., and Taylor, B. A. (1986). Close linkage of mouse genes for salivary proline-rich proteins (PRPs). Am. J. Hum. Genet., 39, A146.

[7] Azen, E. A. and Yu, P. L. (1984). Genetic polymorphism of CON1 and CON2 salivary proteins detected by immunologic and concanavalin $\mathrm{A}$ reactions on nitrocellulose with linkage of $C O N 1$ and $C O N 2$ genes to the SPC (salivary protein gene complex). Biochem. Genet., 22, 1-19.

[ 8 ] Azen, E. A. and Yu, P. L. (1984). Genetic polymorphism of $\mathrm{Pe}$ and Po salivary proteins with probable linkage of their genes to the salivary protein gene complex. Biochem. Genet., 22, 1065-1080.

[9] Azen, E. A. and Oppenheim, F. G. (1973). Salivary 
proline-rich human salivary proteins. Science, 180 , 1067-1069.

[10] Bennick, A. (1982). Salivary proline-rich proteins. Mol. Cell. Biochem. 45, 83-93.

[11] Cramer, D. V. (1981). Genetic variation of urinary pepsinogen and its probable linkage to albinism in the rat. Immunogenetics, 13, 555-558.

[12] Dlouhy, S. R. and Karn, R. C. (1983). The tissue source and cellular control of the apparent size of androgen binding protein ( $\mathrm{Abp}$ ), a mouse salivary protein whose electrophoretic mobility is under the control of sex-limited saliva pattern $(S s p)$. Biochem. Genet., 21, 1057-1070.

[13] Dlouhy, S. R. and Karn, R. C. (1984). Multiple gene action determining a mouse salivary protein phenotype: Identification of the structural gene for androgen binding protein (Abp). Biochem. Genet., 22, 657-667.

[14] Fernandez-Sorensen, A. and Carlson., D. M. (1974). Isolation of a proline-rich protein from rat parotid glands following isoproterenol. Biochem. Biophys. Res. Commun., 60, 249-256.

[15] Finlayson, J. S., Asofsky, R., Potter, M., and Runner, C. C. (1965) . Major urinary protein complex of normal mice: origin. Science, 149, 981-982.

[16] French, C. A., Roberts, K. B., and Searle, A. G. (1971). Linkage between a hemoglobin locus and albinism in the Norway rat. Biochem. Genet. , 5, 379 -404 .

[17] Friedman, R. D. and Merritt, A. D. (1975) . Partial purification and characterization of a polymorphic protein $(\mathrm{Pa})$ in human parotid saliva. Am.J. Hum. Genet., 27, 304-314.

[18] Gedde-Dahl, T., Korsnes, L., Thorsby, E., Olaise, B., Bratlie, A., and Siverts, A. (1978). Pepsinogens: new variant and linkage relationships to chromosome 6 marker. Cytogenet. Cell Genet., 22, 301-303.

[19] Hudson, D. M., Finlyson, J. S., and Potter, M. (1967). Linkage of one component of major urinary protein complex of mice to the brown coat color locus. Genet. Res., 10, 195-198.

[20] Ikemoto, S., Minaguchi, K., Suzuki, K., and Tomita, K. (1977). New genetic marker in human parotid saliva. Science, 197, 378-379.

[21] Karn, R. C., Dlouhy, S. R., Springer, K. R., Hjorth, J. P., and Nielsen, J. T. (1982). Sex-limited genetic variation in a mouse salivary protein. Biochem. Genet., 20, $493-504$.

[22] Karn, R. C., Goodman, P. A., and Yu, P. L. (1985). Description of a genetic polymorphism of a human proline-rich salivary protein, $\mathrm{Pc}$, and its relationship to other proteins in the salivary protein complex (SPC). Biochem. Genet., 23, 37-51.

[23] Kauffman, D. L., Wong, R., Bennick, A., and Denniston, C. L. (1982). Basic proline-rich proteins from human parotid saliva : Complete covalent structure of protein 1B-9 and partial structure of protein 1B-6, members of polymorphic pair. Biochemistry, 21, 6558-6562.

[24] Kondo, Y., Hamada, S., Serikawa, T., and Yamada, J. (1987). Two polymorphic genetic loci of rat tear proteins. Transplant. Proc., 19, 3146-3147.

[25] Kondo, Y., Hamada, S., Serikawa, T., and Yamada, J. (1987). Genetic polymorphism of tear protein in the rat. Biochem. Genet., 26, 683-691.

[26] Kondo, Y., Hamada, S., Serikawa, T., and Yamada, J. (1989). Second genetic polymorphism of tear proteins in the rat (Rtp-2) . Exp. Anim. , 38, 327 -331 .

[27] Kondo, Y., Serikawa, T., Yasue, T ., and Yamada, J. (1993) . Genetic polymorphisms of salivary protein in the rat. Exp. Anim., 42, 83-88.

[28] Kondo, Y. and Yamada, J. (1983). Male urinary protein $-1(M u p-1)$ expression in the female rat. $J$. Hered., 14, 280-282.

[29] Kondo, Y. and Yamada, J. (1983). Polymorphism in $\mathrm{Pg}-1$ (urinary pepsinogen-1) locus in the rat and its linkage analysis. Exp. Anim., 32, 51-54.

[30] Mamura, P. W., Morley, D. J., Larsen, S. H., and Karn, R. C. (1988). Expression of human salivary protein genes. Biochem. Genet., 26, 165-175.

[31] Matsushima, Y. and Ikemoto, S. (1981). Biochemical genetic and sexual variations in mouse tear protein. Jpn. J. Zootech. Sci., 52, 775-779.

[32] Matsushima, Y. and Ikemoto, S. (1982). Genetic analysis of mouse salivary protein system-1.Jpn.J. Zootech. Sci., 53, 617-621.

[33] Matsushima, Y. and Ikemoto, S. (1983). Genetic analysis of mouse tear protein system $-1(M t p-1)$. Jpn. J. Zootech. Sci., 54, 269-274.

[34] Matsushima, Y. and Ikemoto, S. (1984). Genetic analysis of mouse tear protein : Linkage of the $M t p-1$ locus on chromosome 7. Jpn. J. Zootech. Sci., 55, 197 -198 .

[35] Matsushima, Y., Imai, T ., and Ikemoto, S. (1984). Evidence for $\mathrm{X}$ linkage of the mouse tear protein system-3 $(M t p-3)$ with mosaic expression in heterozygous females. Biochem. Genet., 22, 577-585.

[36] Moutier, R., Toyama, K., and Charrier, M. F. (1973). Biochemical polymorphism in the rat, Ruttus norvegicus : genetic study of four markers. Biochem. Genet., 8, 321-328.

[37] Muenzer, J., Bildstein, C., Gleason, M., and Carlson, D. M. (1979). Purification of proline-rich proteins from parotid glands of isopratenol-treated rats. J. Biol. Chem., 254, 5623-5628.

[38] Nikaido, H., Yamada, J., and Kondo, Y. (1982). Male urinary protein-1 (MUP-1) in the rat: Mup-1 assigned to linkage group II . J. Hered ., 73, 119-122.

[39] Preston, S. L. and McMorris, F. A. (1983). An electrophoretic variant of 6-phosphogluconate dehydrogenase in rat and its application in detecting somatic cell hybrids. Biochem. Genet., 21, 161-165.

[40] Samloff, I. M. (1969). Slow moving protease and the seven pepsinogens. Electrophoretic demonstration of the existence of eight proteolytic fractions in human gastric mucosa. Gastroenterology, 57, 659-669.

[41] Sapse, A. T., Bonavida, B., Stone, W. Jr., and Sercarz, E. E. (1969). Proteins in human tears. I. Immunoelectrophoretic patterns. Arch. Ophyhalmol., 81, 815-819.

[42] Seller, A. L., Roberts, S., Rask, I., Smith, S., Manmostan, J., and Goodman, H. C. (1952). An electrophoretic study of urinary protein in rat. $J$. Exp. Med., 95, 465-472.

[43] Serikawa, T., Kuramoto, T., Hilbert, P., Mori, M., Yamada, J., Dubay, C. J., Lindpainter, K., Ganten, D., and Guénet, J.-L. (1992). Rat gene mapping using PCR-analyzed microsatellites. 
Genetics, 131, 701-721.

[44] Szoka, P. R. and Paigen, P. (1978). Regulation of mouse major urinary protein production of the $M u p-a$ gene. Genetics, 90, 597-612.

[45] Szymura, J. M. and Klein, J. (1981). Linkage of a gene controlling urinary pepsinogen with the major histocompativility complex of the mouse. Im munogenetics, 13, 267-271.

[46] Szymura, J. M. and Klein, J. (1982). Mapping of the mouse Upg-1 locus. Immunogenetics, 16, 89-95.

[47] Szymura, J. M., Taylor, B. A., and Klein, J. (1982). Upg-2: urinary pepsinogen variant located on chromosome 1 of the mouse. Biochem. Genet., 20, 1211-1219.

[48] van Zutphen, L. F. M., Lagerwerf, A., Bouw, J., and den Bieman, M. G. C. W. (1981). Biochemical polymorphism in the rat: genetics of three electrophic variants and characterization of inbred strains. Biochem. Genet., 19, 173-186.

[49] Weitkamp, L. R., Towner, P. L., and May, A. G. (1975). Further data on possible linkage between $H L A$ and $a$ locus controlling urinary pepsinogen 5 . Am. J. Hum. Genet., 27, 486-491.

\title{
ラット尿，涙液および唾液から検出される 標識遺伝子座の研究
}

近 藤 靖

\author{
田辺製薬株式会社安全性研究所
}

ラットにおける標識遗伝子座として利用価值の高 い生化学的遺伝子座の開発を目的として, 生体のまま 容易に採取可能な, 尿, 涙液および唾液を試料とした 電気泳動を行い, 幾つかの蛋白あるいは酵素に遺伝的 多型を見いだした。ラット尿 pepsinogenの電気泳動 による多型を支配する遺伝子座 $(P g-1)$ がアルビノ遺 伝子座（LG I） と連銷があるという報告（Cramer， 1881）に基づき, Pg-1 (urinary pepsinogen-1), c, および $H b b$ 遺伝子座の 3 点テストを行った結果, $P g-$ 1 は $\mathrm{c}$ とも $H b b$ とも連鎖が認められず，LG I には属 さないことが強く示唆された。また，雌尿を濃縮する ことにより，ポリアクリルアミドゲルを支持体とした 電気泳動法により, 雌からも雄の泳動型とは少し異な るものの, MUP-1 蛋白を検出することができた。の 蛋白の発現を支配する遺伝子座は, 雄 $M u p-1$ (male urinary protein-1) 遺伝子座同様 LG IIの $b$ 遺伝子座 と連鎖していることを確認した。涙液蛋白中からは, アガロースゲルを支持体とした電気泳動法により 2 種類の遺伝的多型を見いだし、これらの蛋白の発現を 支配する遺伝子座を，それぞれRtp-1 (rat tear protein-1）およびRtp-2 (rat tear protein-2) と命名し
た。Rtp-1 は LG IIに属し, Mup-1 と非常に近い位置 にある遺伝子坐であることが確認された。また, RTP1 蛋白は, 抗ラット MUP-1 抗体を用いて, MUP-1 蛋 白と共通抗原を持つことが確かめられた。RTP-1 は MUP-1 と異なる蛋白ではあるものの, その遺伝子の 染色体上の位置は非常に接近しており, その産物が同 じ抗原性を持つことから，同一の遺伝子ファミリーに 属するものと推察された。Rtp-2 は LG I の c とゆる く連鎖しており，両遺伝子座間の組換価は $36.7 \pm 5.4$ \%であった。唾液蛋白中からも, ポリアクリルアミド ゲルを支持体とした電気泳動法により，2 種類の遺伝 的多型を見いだし，これらの蛋白の発現を支配する遺 伝子座を，それぞれ $R s p-1$ (rat salivary protein-1) および Rsp-2（rat salivary protein-2）と命名した。 $R s p-1$ は LG I, II, IV, Vならびに $A c p-2$ および $P g-1$ を含む LG には属さず, $R s p-2$ は LG I, II, $\mathrm{V}, \mathrm{X}$ ならびに $A m y-1, E s-6 お よ ひ ゙ P g-1$ を含む LG に属さないことが判明した。これらの遺伝子は, ラッ 卜近交系間に広く多型が存在していること, また生体 のまま容易に採取可能なことから, 有用な標識遺伝子 になるものと考えられた。 